\title{
Makna Tinder sebagai Tempat Mendapatkan Teman Hidup
}

\author{
Annisarizki \\ Program Studi Ilmu Komunikasi, FISIP, Universitas Serang Raya \\ E-mail: annisarizzkii@gmail.com
}

\begin{abstract}
ABSTRAK
Tinder adalah salah satu aplikasi pencarian jodoh online yang ramai digunakan. Tinder memberikan perubahan cara masyarakat dalam menemukan teman hidup, dahulu proses mendapatkan teman hidup di awali dengan perkenalan secara tatap muka, melewati tahapan pendekatan dengan pasangan, tahapan penjajakan untuk mengenal satu sama lain, setelah itu baru ke arah intim dengan melakukan kencan. Namun saat adanya Tinder waktu yang dibutuhkan tidak lama untuk memutuskan menikah dengan orang baru dalam kehidupan mereka, hal ini yang membuat peneliti tertarik untuk mengetahui bagaimana fenomena pencarian teman hidup melalui aplikasi jodoh online mengenai makna Tinder sebagai tempat mendapatkan teman hidup. Teori yang digunakan dalam penelitian ini adalah teori Computer Mediated Communication (CMC) dan teori Penetrasi Sosial. Penelitian ini juga menggunakan metode fenomenologi dengan pendekatan kualitatif. Hasil penelitian menunjukan bahwa informan menggunakan Tinder karena ajakan dari teman. Mereka mengalami keterbatasan waktu dan lingkungan, maka mereka menjadi media sosial (Tinder) sebagai solusi mendapatkan jodohnya. Tetapi mereka tetap menyeleksi pasangan yang match di Tinder sesuai dengan kriteria yang mereka di dunia nyata, untuk mereka ajak menikah.
\end{abstract}

\begin{abstract}
Tinder is one of the online dating search applications are busy used. Tinder provides a change in the way society finds friends, the process of getting a life partner begins with face-to-face introductions, passing approach stages with partners, exploring stages to get to know each other, then being intimate with dates. But when Tinder takes the time it takes not long to decide to marry someone new in their life, this is what makes the researcher interested to know how the phenomenon of searching a friend live through online dating application about the meaning of Tinder as a place to get a life partner. The theory used in this research is Computer Mediated Communication (CMC) theory and Social Penetration theory. This research also uses phenomenology method with qualitative approach. The results showed that the informants used Tinder because of the invitation from friends. They have limited time and environment, so they become social media (Tinder) as a solution to get the soul mate. But they still select the match couples in Tinder according to the criteria they are in the real world, for they get married.
\end{abstract}




\section{PENDAHULUAN}

Perkembangan teknologi komunikasi saat ini tidak bisa dipisahkan dari kehidupan masyarakat, melainkan menjadi sebuah jawaban untuk memenuhi kebutuhan informasi masyarakat. Konsumsi masyarakat akan informasi di mudahkan oleh hadirnya teknologi komunikasi yang semakin hari semakin canggih dan difasilitasi oleh internet, hal ini berdampak pada perubahan perilaku berkomunikasi dalam berinteraksi di kehidupan masyarakat. Komunikasi yang dulunya memerlukan waktu yang lama dalam penyampaiannya, kini dengan teknologi segalanya menjadi sangat dekat dan tanpa jarak maupun letak geografis masyarakat. Menurut McLuhan (dalam Morissan, dkk, 2010: 31), teknologi komunikasi menjadi penyebab utama perubahan budaya. Kehidupan keluarga, lingkungan kerja, sekolah, pertemanan, kegiatan keagamaan, politik, dan sebagainya semua terpengaruh teknologi komunikasi.

Perubahan budaya akibat teknologi komunikasi terlihat dari pola masyarakat Indonesia yang ketergantungan tinggi dengan teknologi informasi. Masyarakat Indonesia menghabiskan rata-rata waktunya sekitar 117 menit di depan computer, 181 menit di depan smartphone, dan 110 menit di depan tablet. Ini artinya rata-rata masyarakat lebih banyak menghabiskan waktu di depan layar smartphone. Berdasarkan data survei APJII 2017 bahwa 88,13\% internet dimanfaatkan untuk bidang gaya hidup yang mengakses media sosial, sedangkan $89,35 \%$ masyarakat mengakses layanan chatting.

Smartphone dengan akses internet dapat mengunduh aplikasi sesuai dengan kebutuhannya, dari aplikasi berbelanja online, aplikasi jual-beli online, aplikasi transportasi online hingga aplikasi pencarian jodoh online yang memiliki fitur chatting untuk menghubungkan para pengguna aplikasi tersebut. Salah satu aplikasi pencarian jodoh terbaik yang sedang digandrungi saat itu adalah Tinder, tentu saja Tinder bukan lah satu-satunya aplikasi pencarian jodoh yang hadir di tengah masyarakat rural maupun urban. Ada beberapa aplikasi pencarian jodoh online yang terbaru saat ini, misalnya; Paktor, Wavoo, Setipe, Gather, dari ke empat aplikasi pencarian jodoh online Tinder paling mendominasi. Aplikasi pencarian jodoh 
online ini diluncurkan pada tahun 2012 oleh Sean Rad, Jonathan Badeen dan Justin Mateen.

Hingga kini, Tinder telah digunakan di 196 negara dengan statistik yang menggagumkan namun tidak mengherankan. Setiap harinya ada 26 juta jodoh yang terhubung di Tinder (Young dalam Https://jalantikus.com diunduh 26 Mei 2018). Dilansir dari CNN dalam sebuah laporan di tahun 2015, berdasarkan survei terhadap 400 responden berusia 18-53 tahun tergambar, orang Indonesia tergolong aktif berkenalan secara online. (Ariska dalam Https://lifestyle.kompas.com diunduh 26 Mei 2018).

Muncul nya aplikasi pencarian jodoh online telah mengubah perilaku pencarian pasangan yang dahulunya, di awali dengan tahapan perkenalan secara tatap muka, pendekatan, melakukan penjajakan dengan waktu yang cukup atau bahkan memakan waktu, intim lalu kencan, jika menemukan kecocokan para pasangan memutuskan untuk menikah. Berbagai macam cerita cinta perjodohan yang terjadi di Tinder, kebanyakan mereka menggunakan Tinder hanya untuk mendapatkan pasangan one night stand atau mengajak hooking up. Istilah hooking up yaitu sebuah kondisi dimana dua orang kencan dengan tujuan hanya main-main dan lebih mendahulukan kepuasan fisik daripada emosional. Namun tidak demikian dengan kisah Maqeba dan Irvan yang di tulis dalam The Bride Dept.

Pertemuan dengan pasangan hidup bisa terjadi di mana saja dan kapan saja dengan cara yang tidak terduga, seperti Maqeba dan Irvan yang bertemu melalui Tinder. Melalui aplikasi mobile yang menggunakan sistem location-based ini, Maqeba dan Irvan menjadi "match" (saling klik "like" sehingga memungkinkan untuk berkirim pesan) dan Irvan langsung mengirim pesan kepada Maqeba. Sebelum bertemu, Maqeba menyangka bahwa Irvan memiliki darah Arab, sedangkan Irvan menyangka Maqeba memiliki postur yang tidak terlalu tinggi. Ketika akhirnya bertemu, keduanya sama-sama kaget karena dugaan mereka salah (Irvan berasal dari Aceh dan Maqeba memiliki postur yang cukup tinggi). Hal tersebut menjadi kenangan lucu yang Maqeba ingat hingga kini. Pertemuan pertama mereka juga berlangsung di luar dugaan, karena mereka mengobrol hingga 3 jam lamanya. Hubungan Maqeba dan Irvan dibilang cukup unik, karena mereka 
bertemu di Tinder dan kedua tidak menjalin hubungan special, seperti kebanyakan pasangan online lainnya. Irvan juga tidak mengadakan proposal yang romantik, namun Irvan setelah pertemuan selang beberapa minggu ingin menikahi Maqeba.

Berbagai penelitian mengenai aplikasi pencarian jodoh online Tinder juga sudah banyak dilakukan, salah satunya adalah penelitian yang dilakukan oleh Merry Fridha dan Meria Octavianti (2016) menyimpulkan bahwa pria pengguna aplikasi Tinder di Jakarta melakukan kencan online di aplikasi pencarian jodoh atas dasar mengisi waktu luang, media hiburan, bak membeli barang melalui online shop.

\section{KAJIAN PUSTAKA}

\section{PERKEMBANGAN MASYARAKAT DAN TEKNOLOGI INFORMASI}

Castells (1996), menyatakan bahwa di era revolusi informasi, selain ditandai dengan perkembangan teknologi informasi yang luar biasa canggih, juga muncul apa yang disebut sebagai kebudayaan virtual riil, yaitu satu system sosial-budaya baru dimana realitas itu sendiri sepenuhnya tercangkup, sepenuhnya masuk ke dalam setting citra maya, di dunia fantasi, yang di dalamnya tampilan tiak hanya ada di layar tempat dikomunikasikan pengalaman, namun mereka menjadi pengalaman itu sendiri (dalam Sugihartati, 2014: 39). Masyarakat yang semula berinteraksi dalam ruang yang nyata dan bertatap muka, dengan kehadiran internet mereka kini bisa berinteraksi dengan siapa pun, tanpa harus dibatasi nilai dan norma, sehingga di kalangan warga masyarakat yang mengembangkan hubungan dalam jejaring computer maupun smartphone, tumbuh subkultur yang khas - yang berbeda dengan masyarakat yang selama ini mengembangkn hubungan sosial tatap muka.

Menurut Castell (2000), kekhasan teknologi informasi bukan terletak pada kemampuannya mengimbas realitas maya ke dunianya, melainkan kemampuannya membangun kemayaan yang nyata atau real virtuality. Dengan kata lain, kehadiran teknologi informasi terbukti mampu menghadirkan efek suatu peristiwa atau entitas secara aktual, padahal peristiwa atau entitas itu sendiri tidak riil (Supeli dalam Hardiman, 2010:338). Dengan kata lain, di sera masyarakat post-industrial, realitas 
sosial bahkan boleh dibilang sudah mati, untuk kemudia diambil alih oleh realitasrealitas yang bersifat virtual, realitas cyberspace. Dunia baru yang dimediasi oleh hadirnya teknologi informasi yang semakin maju dan supercanggih telah melahirkan hal-hal yang serba virtual: kebudayaan virtual dan komunitas virtual (virtual community).

Seperti dikatakan piliang (2004:64), bahwa di era revolusi informasi, masyarakat memang masih berinteraksi satu dengan yang lain, tetapi kini tidak lagi dalam komunitas yang nyata, tetapi di dalam komunitas virtual. Internet sebagai satu bentuk jaringan komunikasi dan informasi global telah menawarkan bentuk komunitas sendiri (virtual community), bentuk realitas sendiri (virtual reality) dan bentuk ruanganya sendiri (cyberspace), sekaligus melahirkan pola konsekuensi sosial yang mungkin tidak terbayangkan bakal terjadi sebelumnya.

Di era masyarakat post-industrial yang didominasi teknologi informasi dan komunikasi, yang terjadi sesungguhnya bukan hanya perubahan dalam pola interkasi sosial dan cara berkomunikasi yang dikembangkan masyarakat, melainkan juga perubahan sikap dan perilaku masyarakat menyingkapi realitas sosial yang ada disekitaran (Sugihartati, 2014:40). Bila dilihat para pengguna tinder melakuakn interaksi guna mencari pasangan untuk menjadi teman hidupnya, bukan hanya sebatas sengaja tetapi memandang tinder sebagai ajang pencarian jodoh online yang dapat membantu mereka dalam mencari teman hidup.

\section{MEDIA SOSIAL}

Media sosial (Social Networking) adalah sebuah media online dimana para penggunanya bisa dengan mudah berpartisipasi, berbagi, dan menciptakan isi meliputi blog, sosial network atau jejaring sosial, wiki, forum dan dunia virtual. Blog, jejaring sosial dan wiki mungkin merupakan bentuk media sosial yang paling umum digunakan oleh masyarakat di seluruh dunia. Andreas Kaplan dan Michael Haenlein mendefinisikan media sosial sebagai "sebuah kelompok aplikasi berbasis internet yang membangun di atas dasar ideologi dan teknologi Web 2.0, dan yang memungkinkan penciptaan dan pertukaran user-generated content". Sementara jejaring sosial merupakan situs dimana setiap orang bisa membuat web page 
pribadi, kemudian terhubung dengan temanteman untuk berbagi informasi dan berkomunikasi. Jejaring sosial terbesar antara lain Facebook, Myspace, dan Twitter. Jika media tradisional menggunakan media cetak dan media broadcast, maka media sosial menggunakan internet. Media sosial mengajak siapa saja yang tertarik untuk berpertisipasi dengan memberi kontribusi dan feedback secara terbuka, memberi komentar, serta membagi informasi dalam waktu yang cepat dan tak terbatas.

\section{Macam-Macam Media Sosial}

Teknologi media sosial sekarang ini memiliki berbagai berbagai bentuk seperti misalnya majalah digital, forum internet, weblog, blog sosial, microblogging, wiki, jejaring sosial, podcast, foto atau gambar, video, rating dan bookmark sosial. Masing -masing memiliki kelebihannya sendiri seperti blogging, berbagi gambar atau foto, video blogging, wall-posting, berbagi musik atau lagu, chaatting, bahkan VoIP atau Voice over IP, dan lain sebagainya.

Macam-macam Jejaring Sosial - Jenis Media Sosial Berikut di bawah ini ada klasifikasi macammacam jejaring sosial berdasarkan fungsi dan kegunaannya (Kaplan,2010:68):

1. Konten kolaborasi (contohnya, Wikipedia)

2. Blog dan microblog (contohnya, Twitter)

3. Situs jejaring sosial berita (contohnya, Digg)

4. Konten Video (contohnya, YouTube)

5. Situs jejaringan sosial (contohnya, Facebook)

6. Game dunia maya (contohnya, World of Warcraft)

7. Situs dunia sosial virtual (contohnya, Second Life, Tinder).

\section{Computer Mediated Communication}

Berbicara mengenai media baru, media sosial merupakan bagian dari media baru, dimana media sosial menjadi sebuah fenomena media yang sulit ditandingi perkembangannya oleh media-media konvensional dan tradisional seperti media massa. Media sosial menjadi dimensi baru berkomunikasi bermedia, selain itu media sosial merupakan turunan dari perkembangan komunikasi bermedia 
computer atau Computer Mediated Communication (CMC). John December (1977) mendefinisikan komunikasi bermedia komputer sebagai proses berkomunikasi manusia dengan menggunakan komputer yang melibatkan sejumlah orang, dalam situasi dengan beragam konteks, yang terjadi dalam proses untuk membentuk media dengan berbagai tujuan (Thurlow et al, 2007:15)

Dalam buku Computer Mediated Communication: Social Interaction and The Internet, mendefinisikan CMC sebagai proses komunikasi manusia yang menggunakan komputer melibatkan orang, disituasikan dalam berbagai konteks, serta melibatkan proses-proses untuk membentuk media dengan tujuan yang beraneka ragam. Selain itu, komunikasi dengan media komputer dapat didefinisikan sebagai interaksi komunikasi yang terjadi lewat dua buah atau lebih komputer yang berhubungan seperti chatting, instant messaging, jejaring sosial, dan email (December, 1997:35)

Teori ini menjadi landasan utama penelitian ini, Computer Mediated Communication sebagai suatu proses komunikasi yang dilakukan oleh para pengguna Tinder sebagai pembentukan media untuk pencarian jodoh online, yang difasilitasi melalui layanan internet. Penggunaan internet yang dapat diakses secara mudah, menjadikan alasan media baru di gandrungi saat ini. Berbagai fasilitas maupun layanan yang ada seperti email, chatting (Yahoo Messenger, Whatsapp, Line) forum-forum di website (Kasus, Tumblr, Flickr), jejaring sosial (Facebook, Twitter, Path, Instagram) dan lain-lain dapat menciptakan hubungan-hubungan baru oleh penggunanya.

\section{Teori Penetrasi Sosial}

Hubungan interpersonal berkembang secara bertahap dan dapat diperdiksi. Teoretikus Irwin Altman \& Dalmas Taylor telah mempopulerkan teori penetrasi sosial, mereka percaya bahwa pembukaan diri adalah cara utama yang digunakan oleh sebuah hubungan ramah-tamah bergerak menuju hubungan yang intim. Meskipun pembukaan diri dapat mengarahkan menuju hubungan yang lebih intim, pembukaan diri juga dapat menyebabkan satu orang atau lebih berada dalam posisi rentan. 
Teori penetrasi sosial menggambarkan suatu pola pengembangan hubungan yang diibaratkan sebagai sebuah proses yang mereka identifikasi sebagai penetrasi sosial. Penetrasi sosial merujuk pada sebuah proses ikatan hubungan dimana individu-individu bergerak dari komunikasi yang lebih intim. Menurut Altman dan Taylor, keintiman disini lebih dari keintiman secara fisik; dimensi lain dari keintiman termasuk intelektual dan emosional, dan hingga pada batasan dimana pasangan melakukan aktifitas bersama (West\&Turner, 2012: 196)

Dikenal 4 tahapan dalam proses pengembangan hubungan interpersonal. Tahapan Pertama (Lapisan Pertama atau Terluar Kulit Bawang): Lapisan kulit terluar dari kepribadian manusia adalah apa-apa yang terbuka bagi public, apa yang biasa kita perlihatkan kepada orang lain secara umum, tidak ditutup-tutupi. Tahap Kedia (lapisan kulit bawang kedua) ini disebut juga dengan tahapan pertukaran afektif eksploratif. Pada tahap ini, di antara dua orang yang berkomunikasi, mulai bergerak mengeksplorasi ke soal informasi yang berupaya menjajagi apa kesenangan masing-masing, misalnya kesenangan dari segi makanan, music, lagu, hobi, dan lain sejenisnya. Tahap Ketiga (lapisan kulit bawang ketiga), yaitu tahapan penukaran afektif yang berupa peningkatan informasi yang lebih bersifat pribadi, dimana masing-masing sudah mulai membuka diri dengan infomasi diri yang sifatnya lebih pribadi, misalnya seperti kesediaan menceritakan tentang problem pribadi. Dengan kata lain dengan tahap ini sudah berani mengungkapkan isi hati. Tahap Keempat (lapisan kulit bawang keempat), yaitu tahapan akhir atau lapisan inti yang disebut juga dengan tahap pertukaran yang stabil. Tahap akhir ini sifatnya sudah sangat intim dan memungkinkan pasangan tersebut untuk memprediksikan tindakan-tindakan dan respon mereka masing-masing dengan baik. Informasi yang dibicarakan sudah sangat dalam dan menjadi inti dari pribadi masing-masing pasangan misalnya mengenai nilai, konsep diri atau perasaan emosi terdalam. (West\&Turner, 2012:198) 


\section{METODE PENELITIAN}

Penelitian ini menggunakan pendekatan kualitatif yang bertujuan untuk mempertahankan bentuk isi dan perilaku manusia dan menganalisi kualitasnya. Penelitian kualitatif berusaha menyediakan apa yang disebut sebagai complex, holistic picture. Maksudnya, penelitian kualitatif berusaha untuk membawa pembacanya ke dalam pemahaman multidimensional dari permasalahan atau isu yang diangkat. Laporan penelitian kualitatif berusaha menampilkan permasalahan dan segala kompleksitasnya. Karena itulah, penelitian kualitatif seringkali time consuming dalam proses analisanya, analisis kualitatif dilakukan dengan mempertimbangkan banyak sekali variabel. Beberapa alasan dalam melakukan penelitian kualitatif yang ditekankan oleh Creswell (1998:17) dan dirasakan penulis adalah :

1. Jika pertanyaan penelitian adalah "apa" dan "bagaimana"

2. Jika topik penelitian perlu dieksplorasi. Maksudnya jika tidak ada teori yang menjelaskan secara detail permasalahan yang akan dikaji sehingga eksplorasi terhadap teori perlu dilakukan.

3. Jika peneliti ingin meneliti manusia dalam natural setting

4. Jika peneliti ingin menulis dalam gaya literatur narasi dan story telling

5. Jika peneliti berperan sebagai active learner yang melakukan penelitian karena ingin mempelajari sesuatu bukan mengujinya.

Penelitian ini juga menggunakan pendekatan fenomenologi. Fenomenologi menjelaskan fenomena perilaku manusia yang dialami dalam kesadaran, dalam kognitif dan dalam tindakan-tindakan perseptual. Fenomenologi mencari pemahaman seseorang dalam membangun makna dan konsep kunci yang intersubyektif. Karena itu, menurut Kuswarno (2009:53) “... penelitian fenomenologis bertujuan untuk mengetahui dunia dari sudut pandang orang yang mengalaminya secara langsung atau berkaitan dengan sifat-sifat alami pengalaman manusia, dan makna yang ditempelkan padanya..."

Moleong (2000:10) menyatakan bahwa penelitian fenomenologi berusaha untuk masuk ke dalam dunia konseptual para subjek yang ditelitinya sedemikian rupa sehingga ia mengeri apa dan bagaimana suatu pengertian yang dikembangkan oleh para subjek di sekitar peristiwa dalam kehidupannya sehari-hari. Dengan kata lain, 
diperlukan "empati” dan interaksi dialektis anata peneliti dan informan melalui metode kualitatif yang dilakukan dengan cara observasi atau pengamatan. Pendekatan fenomenologi memandang tingkah laku tidak dipengaruhi oleh pengalaman-pengalaman masa lalu, tetapi oleh makna-makna pribadi yang masingmasing individu melekatkannya pada persepsinya mengenai pengalaman tersebut.

\section{PEMBAHASAN}

Dalam penelitian ini, peneliti melakukan pengumpulan data wawancara dan observasi secara online dan offline. Pengumpulan data secara observasi online, dimana peneliti mengunduh aplikasi Tinder dan menggunakannya. Hal tersebut dilakukan guna mengetahui aktivitas yang terjadi di Tinder, sekaligus untuk mengetahui penggunaan aplikasi tersebut. Selain itu untuk melengkapi data, peneliti pun melakukan wawancara secara offline kepada ketiga informan mengenai aktivitas di Tinder dan saat informan bertemu langsung dengan teman kencan onlinenya yang kini menjadi teman hidupnya.

Informan dalam penelitian ini berjumlah tiga orang, yaitu: Simsong seorang wirausaha berusia 28 tahun, AG berusia 27 tahun karyawan swasta, dan RN berusia 30 tahun karyawan swasta. Ada dua informan yang tidak mengijinkan identitas aslinya disebutkan dalam penelitian ini, berdasarkan kesepakatan bersama peneliti menggunakan inisial untuk penulisan nama informan.

Ketiganya informan ini mendapatkan pasangan hidupnya melalui aplikasi tinder dan mereka tidak membutuhkan waktu yang lama untuk memutuskan menikah. Hampir ketiga informan membutuhkan waktu selama dua minggu untuk memutuskan bertemu, setelah mereka match di Tinder kemudian saling bertukar nomer handphone dan chatting beralih ke whatsapp. Pertemuan atau yang sering di sebut meet-up antara pasangan di tinder terjadi , apabila terdapat kecocokan pada saat mereka melakukan chatting via whatsapp. Hubungan interpersonal mereka akan terlihat dari ketertarikan satu sama lain pada saat kencan atau pun setelah kencan. Rasa ketika chatting dengan bertemu akan berbeda, dari ketiga informan merasa canggung untuk pertemuan pertama, namun pengembangan hubungan akan berjalan pada saat mereka membuka diri masing-masing mengenai siapa diri 
mereka dan ada ketertarikan satu sama-lain. Setelah pertemuan tersebut dan menjalin komunikasi tanpa ada komitmen. Kedua informan hanya membutuhkan waktu 1 - 3 bulan dan satu informan membutuhkan waktu 6 bulan untuk memutuskan menikah dengan pasangan Tindernya.

\section{Ajakan dari Teman untuk Memainkan Aplikasi Tinder}

Melalui hasil wawancara dengan informan diketahui ketiga informan mengatakan bahwa awalnya mereka mengetahui aplikasi tinder dan menggunakan aplikasi tinder diajak temannya. Seperti yang disampaikan simpsong "tau dari temen, jadi yang duluan make tuh temen gue sebenernya gue tuh tau karena dikasih tau temen, dia duluan yang make terus yaa udah gue ikutan, gara-garanya ya gitulah, coba deh main ini biar ga bengong.. awalnya cuman pengen ada namanya patner ngobrollah ceritanya tapi lawan jenis" hampir sama dengan yang disampaikan AG, "maen Tinder ini, karena ingin mengenal dan tau lebih banyak lagi karakteristik perempuan, dan dulu kan temen-temen kampus pada pake tinder. Tapi emang digunain pas lagi ngga iseng ngga ada kerjaan atau kalau dulu lagi ngga ada revision skripsi hahaha.."

Sedangkan RN, mengatakan bahwa ia mengetahui aplikasi Tinder dari temannya. RN yang memang sudah meniatkan menggunakan aplikasi Tinder untuk mencari jodoh, pekerja freelance ini tidak satu dua kali berkencan melalui aplikasi Tinder dan bisa di bilang sering. RN mengatakan bahwa "Temennya temen aku dia dapet jodohnya dari tinder, terus ada yang dapet pasangannya bule dari tinder sebentar lagi mereka menikah juga" jadi pernyataan informan diatas dapat diketahui menggunakan Tinder memang motif awalnya diajak teman untuk menggunakan Aplikasi Tinder untuk mencari teman mengobrol yang lawan jenis dan berniat mencari calon untuk dinikahi, selain itu aplikasi ini memang sedang banyak digunakan oleh para pengguna internet baik di Indonesia maupun di luar negri. 


\section{Mencari Lingkungan Baru Untuk Mendapatkan Jodoh}

Kesibukan bekerja membuat informan merasa kesulitan mencari dan mendapatkan jodoh, hal ini di sebabkan oleh faktor internal dalam diri informan yang merasa lingkup pertemanannya mulai mengecil. Berdasarkan pengalaman informan mereka mengungkapkan semakin dewasa nya atau semakin berumurnya membuat mereka dituntut pada keinginan menikah, Tinder menjadi salah satu solusi para informan untuk menemukan jodoh di lingkungan baru dengan berbagai banyak karakteristik perempuan maupun lelaki d Indonesia bahkan luar negri.

Simsong salah seorang informan mengatakan bahwa "karena ada faktor keterbatasan..lingkungan pekerjaan gitu loh, maksud gue orang-orang kerjaan kantoran gitukan setiap hari keluar rumah sedangkan gue diem aja di rumah..diem aja gitu dirumah paling kalau misalkan menuhin market baru keluar...”. Pekerjaan nya sebagai wirausaha tidak membuatkan sering bergaul diluar lingkungan pertemanannya, sehingga ia memutuskan untuk menggunakan aplikasi tinder yang memang ia rasa mudah untuk mengoperasikannya. Hal serupa disampaikan oleh AG "setiap hari kerja.. belum lagi kalau ada event diluar kota, kesibukan kerja jadi susah buat ketemu orang baru, merasa ngga nemu di lingkungan pertemenan sama pekerjaan. Mhh.. sosial media menjadi solusi mendapatkan orang baru diluar kehidupan yang biasanya..”. Sedangkan menurut RN “..kaya dulu cari pacar masih bisa bilang ke temen, eh cariin dong lo punya stok ngga, tapi sekarang itu kayanya stok pada abis yaa ga sih? Kalau minta ke temen itu kaya mereka bilang stok gue udah pada nikah gitu.."

Melalui wawancara diatas terlihat bahwa aplikasi Tinder digunakan sebagai media baru yang menciptakan lingkungan baru untuk mencari jodoh bagi para pekerja yang merasakan keterbatasan berkenalan di dunia nyata dan waktu untuk bersosialisasi dengan lingkungan baru, maka kencan melalui tinder ini mendapatkan pengalaman baru dengan people random yang berbeda dengan kehidupan sebelumnya. 


\section{Melakukan Seleksi dari yang Match sesuai Kebutuhan.}

Melalui hasil wawancara dengan infroman diketahui, mereka melakukan seleksi terhadap teman tinder yang match dengan berbagai cara. Penyeleksian ini dilakukan dikarenakan informan memiliki niat untuk mencari pasangan hidup yang serius. Seperti yang dikatakan Simsong: “...gue swipe ke kanan semuanya nah, sampe nanti ada tuh muncul yang match nya tuh berapa..nah dari situ mulai proses gue pun menyeleksi gitu.. wah ini kurang cakep ngga jadi, wah kayanya ini centil nih gitu kan ngga jadi”

salah seorang informan mengatakan alasan penyeleksian ini di bagi menjadi dua seperti yang dikatakan AG: "kalau aku sih seleksinya ada dua mana cewe yang bisa di enakin sama di seriusin". Sedangkan RN mengatakan "yaa harus selektif, kalau ngga, udah di seleksi aja masih ngaco.. kalau aku ngeliat nya dari umur. pernah ketemuan kayanya umurnya 24 atau berapa yah atuhlah masa beda 4 tahun gila, dan itu karena dia bilang salah masukin umur di bio nya dan ngga bisa di rubah lagi"

dalam hal ini, informan merasa dirinya harus selektif dalam menentukan siapa yang mereka suka berdasarkan kriteria yang mereka miliki, informan memiliki kriteria tersendiri yang sesuai dengan dirinya dan dunia nyatanya. Ketika match dengan pengguna Tinder lainnya, mereka melalui proses interaksi melalui ruang obrolan hingga akhirnya para informan memutuskan untuk bertemu secara kopi darat atau face to face.

\section{Fenomena Pencarian Teman Hidup Melalui Aplikasi Pencarian Jodoh Online}

Tinder merupakan aplikasi kencan online berbasis GPS yang diliris pada bulan September 2012. Finkel et al (2012) menyatakan bahwa aplikasi kencan online seperti Tinder termasuk kedalam bentuk sistem kencan online generasi ketiga yang memiliki karakteristik hanya dapat di akses melalui smartphone menggunakan sistem GPS dalam pemanfaatnya. Aplikasi Tinder menjadi aplikasi kencan online yang sangat diminati oleh kamum dewasa muda, umur rata-rata 
pengguna Tinder sendiri berkisar di usia 23 tahun (Robehmed, 2013). Internet muncul dan mengubah pola komunikasi interpersonal kalangan dewasa muda, khususnya lingkup kencan online yang menuju pada pencarian jodoh online.

Para informan menggunakan aplikasi Tinder untuk mencari pasangan romantik jangka panjang yang serius. Para pengguna mendambakan hubungan online yang dibangun melalui Tinder akan terus berlanjut menjadi hubungan romantic di dunia nyata. Untuk sampai pada tahap serius ke hubungan romantik dengan jangka panjang atau bisa di bilang dengan tahapan hubungan serius kearah pernikahan, para informan harus melewati 4 tahapan yang dianalogikan sebagai kulit bawang. Analogi kulit bawang melihat proses pengembangan hubungan interpersonal melaui keterbukaan seseorang terhadapat lawan jenisnya.

Lapisan paling awal dari interaksi, disebut sebagai tahap orientasi. Pada tahap ini hubungan akan bergerak menjadi sebuah hubungan yang menuju ke hubungan yang lebih intim, tahap orientasi dilakukan oleh informan RN, AG dan Simpsong pada saat proses pencarian pasangan yang dilakukan dalam bentuk sistem swiping. Ketika pengguna membuka home akun Tinder nya, pengguna akan menentukan pilihan teman kencan yang ia mau berdasarkan foto profil, bio dan umur. Hal ini seperti disampaikan AG, dalam sebuah wawancara "kalau AG sih, nyarinya yang pake jilbab. Yang ceker babat gitu.. cewe cantik bikin pengen taubat.. hahhaa makanya dapetnya yang sekarang pake jilbab".

Pada tahap orientasi para infroman berhati-hati untuk tidak membuka diri terlalu banyak terhadap satu sama lain, walaupun pada tahap orientasi ini sudah melakukan chatting tinder dan berkomunikasi dengan match di ruang obrolan. Di ruang obrolan dengan matches akan menentukan pengembangan hubungan yang mereka inginkan, hal ini dilihat pada keterbukaan dan kesempatan yang diberikan secara sukarela untuk melanjutkan percakapan di aplikasi layanan lnstant messaging WhatsApp.

Selanjutnya para informan memasuki mencari tau lebih dalam mengenai siapa dan bagaimana pasangan match nya, melalui chatting di WhatsApp. Menurut mereka chatting menjadikan proses lebih mudah sebagai sarana pertukaran informasi. Proses interaksi melalui chatting ini yang akan menentukan 
pengembangan hubungan dan keintiman dengan yang match, pengembangan hubungan pada tahap ini biasanya menentukan mereka untuk mengajak bertemu secara face-to-face di dunia nyata atau tidak. Dari hasil wawancara terlihat bahwa informan memasuki dan melakukan tahap kedua pertukaran penjajakan afektif, mereka memperluas area publik dari diri dan terjadi ketika aspek-aspek dari kepribadian seorang individu mulai muncul dan mereka pun berharap pasangan match nya melakukan hal sama, seperti yang disampaikan simsong "..orang yang ngga kenal jadi bisa pendekatannya itu cuma lewat awal via WhatsApp gitu dong, kalau emang oke yaa lanjut baru ketemuan gitu gimana-gimananya"

Pada tahap kedua, pertukaran penjajakan afektif tidak semua berjalan lancar sampai dengan ketemuan (face-to-face), mereka sering berhenti pada tahap ini. Ada beberapa faktor yang menyebabkan pengembangan hubungan tidak berjalan dengan lancar, salah satunya adalah adanya rasa ketakutan atau rasa minder ketika ditanyai soal pekerjaan utama. Seperti yang diungkapkan simsong "pernah deket sama cewe, dia kerja di agent umroh admin gitu. Awalnya obrolannya udah enak cuman lagi-lagi mentok ketika ditanya gut uh profesi utamanya apa, apa yang bisa menjadikan gue menopang hidupnya dia”. Lain hal dengan informan yang lainnya mereka mengakhiri hubungan di tahap penjajakan ini, karena merasa tidak ada kecocokan pada saat chatting. Namun dari beberapa yang match informan AG dan Simsong hanya melakukan satu kali pertemuan dengan yang match, yaitu yang menjadi pasangan saat ini. Ketiga informan memutuskan untuk bertemu dengan waktu yang singkat, dalam kurun dua minggu chatting di WhatsApp sambil mencari info yang lainnya tentang pasangan matchnya. Media sosial lain sebagai second options untuk mengetahui latar belakang pasangannya, oleh karena itu mereka saling menfollow akun Instagram.

Setelah bertemu secara tatap muka dengan pasangan match nya yang ditemukan di aplikasi Tinder, ketiga informan tersebut berhasil membentuk dan berkomunikasi lebih intens dengan komitmen hanya sebagai teman dekat dulu awalnya. Komunikasi tetap berjalan lancar bahkan meningkatan pada tingkatan saling menghubungu via telfon sampe pada akhirnya video call, proses interaksi pada saat ini membuat intensitas komunikasi meningkat. Disisi lain peningkatan 
dalam keinginan berkomitmen bukan hanya sekedar berkencan tapi lebih pada komitmen untuk menikah.

Pertukaran afektif ditandai dengan adanya kenyamanan dan komitmen yang semakin merasakan intim dengan pasangannya. Interaksi yang dilakukan pada tahap ini membuat informan menjalaninya dengan santai dan tanpa beban, dimana komunikasi berjalan lebih spontan dan individu membuat keputusan yang cepat. Sering kali memberikan perhatian untuk hubungan secara keseluruhan, sehingga membuat rasa rindu bila tidak bertemu maupun tidak berkomunikasi. Pengembangan hubungan seperti itu sudah mencapai tahap integrating yang ditandai dengan adanya rasa berbagi perhatian dan hubungan mutulisme. Proses interaksi dilakukan dengan menyampaikan keinginan-keinginan dan tujuan membangun hubungan secara intim yang jelaskan secara serius, berserta pengalaman-pengalaman masa lalu yang gagal dalam menjalin hubungan serius di kehidupan sebelumnya.

Pada tahap ini para informan sudah tidak memikir fisik secara keseluruhan, misalnya: berat badan dan tinggi badan pasangan matchnya. Mereka mengetahui konsekuensi yang akan didapatkan bila melakukan blind date, meskipun setelah pertemuan mereka mengakui bahwa pasangan mereka bukan lah tipe mereka secara keseluruhan, namun mereka merasakan kenyamanan dan kebutuhan utama yang diinginkan sudah terpenuhi. Seperti yang dikatakan RN “..soalnya gue pikir dia orangnya gede, gitulah ternyata dia kecil, terus pas ketemu yah pas dia udah berdiri nyampe di mall gitu, ngebatin kayanya bukan tipe gue.. no.no..no, bukan tipe gue tapi nyaman gimana sih. haahaaha". Hal serupa juga di alami oleh informan lainnya, namun keinginan untuk mereka untuk menikah tidak memikirkan tentang berat badan dan tinggi badan. Kenyamanan telah meruntuhkan tipe pasangan hidup, bahkan mereka mendapatkan sesuatu yang lebih dari hanya sekedar berapa tinggi badan dan berapa berat badan pasangannya. Simpsong menngatakan”..yaa karena diluar hal itu ada sesuatu utama yang udah dia penuhi, tapi gini yaa gue baru tahu dia bokongnya gede banget terus yaa Allah gede banget tapi yaa bodoamat.."

Selanjutnya adalah tahap terakhir atau lapisan kulit bawang yang paling dalam. Memasuki tahapan pertukaran stabil, tahap ini adalah tahapan yang 
membuat yakin untuk menikah dengan pasangan matchnya. Keyakinan tumbuh karena pasangan match mereka dapat menerima segala sesuatu yang ada di dalam diri mereka, baik itu profesi dan fisik informan. Tahap pertukaran stabil berhubungan dengan pengungkapan pemikiran, perasaan dan perilaku secara terbuka yang mengakibatkan spontanitas dan keunikan hubungan yang tinggi. Perilaku-perilaku yang menjadi kebiasaan diantara keduanya kadang kala terjadi kembali dan pasangan mampu untuk menilai dan menduga perilaku pasangannya dengan cukup akurat.

Perilaku yang tidak disukai atau kebiasaaan yang tidak muncul diawal mulai muncul secara spontan, semua itu diterima oleh para informan. Hal ini karena mereka telah mempunyai kesempatan untuk mengklarifikasi setiap ambiguitas yang pernah ada dan mulai membentuk sistem komunikasi pribadi yang lebih fleksibel.

\section{SIMPULAN}

Pembukaan diri tergantung pada sejumlah faktor, tidak hanya pada kebutuhan untuk membuka diri sejalan dengan waktu. Individu secara konstan berubah, yang dianggap sebagai pembukaan diri dalam analogi kulit bawang di teori Penetrasi Sosial sering kali tergantung pada sikap pasangan. Mencari pasangan hidup di Tinder dimaknai sebagai bentuk lingkungan baru untuk bertemu orang baru yang karakternya bebeda dengan pengalaman-pengalaman sebelumnya, selain itu mengunakan aplikasi Tinder dikarenakan ajakan teman yang mendapatkan jodoh melalui Tinder, walaupun dalam pencarian jodoh online mereka harus melakukan seleksi yang sesuai dengan dirinya di dunia nyata. 


\section{DAFTAR PUSTAKA}

Creswell, John W. 1998. Qualitative Inquiry and Research Design . California: Sage.

December, John. 1997. Computer Mediated Communication: Social Interaction and The Internet. London: Sage Publication: Florida.

Finkel, et al. 2012. Online Dating: A Critical From The Perspective of Psychological Science. Psychological Science in the Public Interest, 11.

Hardiman, F. Budi. 2003. Melampaui Positivisme dan Modernitas, Diskursus Filosofis tentang Metode Ilmiah dan Problem Modernitas. Yogyakarta: Kanisius.

Kaplan, Andreas M.; Michael Haenlein (2010) "Users of the world, unite! The challenges and opportunities of Social Media". Business Horizons 53(1): 59-68

Kuswarno, Engkus. 2009. Fenomenologi. Bandung : Widya Padjajaran.

Moleong, lexy J. 2000. Metode Penelitian Kualitatif Edisi Revisi. Bandung: Remaja Rosdakarya.

Morissan, Andy Corry Wardhani \& Farid Hamid. 2010. Teori Komunikasi Massa. Bogor: Ghalia Indonesia.

Piliang, Yasraf Amir. 1998. Sebuah Dunia yang dilipat, Realitas Kebudayaan Menjelang Milenium Ketiga dan Matinya Postmodern. Bandung: Mizan.

Sugihartati, Rahma. 2014. Perkembangan Masyarakat Informasi \& Teori Sosial Komtemporer. Jakarta: Kencana.

Thurlow dkk. 2004. Computer Mediated Communication Social Interaction and The Internet. London: Sage Publication: Florida

West, Ricard \& Lynn H. Turner. 2012. Pengantar Teori Komunikasi, Analisis dan Aplikasi. Terjemahan dari Introducing Communication Theory: Analysis and Application. Jakarta: Salemba Humanika. 